\title{
On Some Dialogue Translation Mistakes in Little Women (1933)—From the Perspective of Skopos Theory
}

\author{
Yan Chang \\ Foreign Language School, Qingdao University of Science and Technology, Qingdao, China \\ Email: changyan27@163.com
}

\begin{abstract}
According to Skopos Theory, the Skopos of translation determines the methods and the strategies in translation. Films are created for the audience with the audience's acceptance and appreciation as the basic principle. Thus the specialty of films requires that translators are supposed to consider more about the audience's expectation horizon, aesthetic taste and ability of acceptance rather than only the source language and cultural information. Adopting German functional classical theory, Skopos theory, as the theoretical base and the previous studies of various aspects of film translation as the practical requirements, this paper attempts to construct a tentative analysis of dialogue translation mistakes in Little Women (1933), with an attempt to illustrate some strategies rather than literal translation should be adopted in film translation to meet its specified requirements and to follow the flow of film.
\end{abstract}

Index Terms—film translation, Skopos Theory, Little Women (1933)

\section{INTRODUCTION}

With the tendency of globalization, international culture exchanges have become more and more popular and significant. One of the most important carriers of human culture, film, has gained fast development and becomes a main method of learning a foreign language. They are also one of the most important elements in the world's cultural communication, which can be regarded as an effective way of promoting mutual understanding between different counties.

Compared to general translation, film translation has its peculiar characteristics-three channels of message transference for translator: visual channel, aural channel and written channel; and harmony between verbal and non-verbal elements for the audience to comprehend and appreciate the translation.

As a primary componential part, film dialogue has its special features. In some films, two or more languages are spoken, while in some others, strong dialects are used to create the dramatic effects. What's more, film dialogues are usually interactive, short, incomplete and informal, and individualized. Excellent translated film can bring to the audience great satisfaction and appreciation both in eyes and ears.

The aim of film dialogue translation is to make the target audience accept and fully appreciate the charm of an authentic foreign film. Film dialogue translation is not only is transference of two languages, but also is a process of transplantation of another culture. It is a purposeful target-culture-audience-oriented translation.

Little Women is of the best-loved books of all times. This great classical novel is written by Lousia May Alcott, an extremely talented American author. Based on Lousia May Alcott's childhood, this lively portrait of nineteenth-century family life story possesses a lasting vitality that has endeared it to generations of readers. The audience has had very deep impression of each individualized character.

This classical literature work has been put onto screen five times, all of which are striking and have left on millions and millions of audience very deep impressions. The first version, Little Women (1933) is still the best interpretation of the original literature work. It won 10 Best Films in 1933 Film Daily and 1933 New York Times, and it also win the Oscar for Best Writing (Adaptation) and was also nominated for Best Picture. This version was such a success that it was a huge box-office hit, and broke all the records to that time.

Although the dialogue translated skillfully, there exist some controversial mistakes. This paper attempts to construct a tentative analysis of dialogue translation mistakes in Little Women (1933), in terms of German functional classical theory, Skopos Theory.

\section{SKOPOS THEORY}

"Skopos" is the Greek word for "aim" or "purpose" and was introduced into translation theory in the1970s by Hans J. Vermeer as a technical term for the Purpose of a translation and of the action of translating. (Vermeer, 2000)

Skopos theory proposes that the translated text may have the same or different functions with the source-text functions. The task of the translator is to produce a new text which can meet the cultural expectations of the receivers on 
the basis of the source-text, with a specific function.

The main idea of Skopos theory is that translation should be purpose-oriented. The most practical part is the principles of Skopos theory which can be applied in the translation practice: the Skopos Rule, the Coherence Rule and the Fidelity Rule.

\section{A. Skopos Rule}

The top-ranking rule for any translation is thus the "Skopos rule"-translate/interpret/speak/write in a way that enables the text/translation to function in the situation in which it is used and with the people who want to use it and precisely in the way they want it to function. Translational action is determined by its Skopos, that is, "the end justifies the means". According to Skopos theories, translation approach and strategy must be determined by the expected (or demanded) function of the translated text. The aim that the translation is going to reach determines the whole translation process. Vermeer explains, each text is produced for a given purpose and should serve this purpose.

\section{B. Coherence Rule (Intratextual Rule)}

The target-text should conform to the standard of "intratextual coherence" which is the second important rule. This means the receiver should be able to understand it; it should make sense in the communicative situation and culture in which it is received. A communicative interaction can only be regarded as successful if the receivers interpret it as being sufficiently coherent within their situation. Accordingly, coherence rule specifies that a translation should be acceptable in a sense that it is coherent with the receivers' situation.

\section{Fidelity Rule (Intertextual Rule)}

Since a translation is an offer of information about a preceding offer of information, it is expected to bear some kind of relationship with the corresponding source text. This is called "intertextual coherence" or "fidelity". Intertextual coherence should exist between source and target text, while the form it takes depends both on the translator's interpretation of the source text and on the translation skopos.

The German functionalist skopos therory is purpose-oriented and noted for advocating the plurality of translation criteria. The decisive factor here is the purpose, the skopos, of the communication in a given situation. In a word, just like a glimpse of sunshine, Skopos theory offers valuable enlightenment to translation study. Thus it seems to have broadened our horizon and helped us to get further comprehension of translation study.

So Skopos theory can account for different strategies in different translation situation, in which source-texts are not the only factor involved. It is pragmatic, accounting for the situational conditions of communicative interaction, and accordingly, for the needs and expectations of the addressees or prospective receivers of the target-text, and even making the target receiver the most important yardstick of translational decisions; it is also consistent, able to establish a coherent theoretical and methodological framework that could serve as a guideline for an inter-subjective justification of the translator's decisions in any type or form of translation task, permitting any translation procedures that would lead to a functional target-text. Thus, it can give the translator a guideline as to the best or safest ways to attain a particular translation purpose.

In skopos rule, intertextual coherence is key point that should lie between source and target text, while the form it takes depends on both translators' interpretation of the source text and on the translation skopos. Intertextual coherence is considered subordinate to intratextual coherence, and both are subordinate to the skopos rule.

\section{Dialogue Translation Mistakes in Little Women (1933)}

Although "Little Women" (1933) is such a hit, the translated version has some controversial problems if thoroughly studied. In this section, here are some ill-translated examples in this film and analysis of them from the point of view of Skopos Theory with suggestive solutions. The comments and suggestions tend to be suggestive and they are open to criticism.

This film focuses on the personal interactions family members have with each other, as well as with their friends and neighbors, in order to create a portrait of an idealized, loving family held together during trying times. As translators, we can make clear the formality of the situation, the age and the educational level of the interlocutors, the relationship of the parties at each scenes, as well as the speaker's intention and attitude. And in addition to that, different rules and norms governing their usage in different cultures should also be taken into consideration. All these constitute part of the translation belief in the point of view of Skopos Theory.

\section{A. Example One}

Teacher: School is dismissed!

Teacher: Amy March! You may close the door!

Girl 1: That'll teach her not to cut up didoes.

Girl 2: It serves that stuck-up Amy March right.

Girl 3: What's he going to do to her?

Teacher: I can see there's nothing for me to do but to stop by and show your mother how instead of doing your sums, you cover your slate with sketches. And most uncomplimentary sketches. 
Amy: Please, Mr. Davis. I'll never do it again, sir. And she'd be so disappointed in me. Please. Please.

Teacher: Well, I should hate to spoil her Christmas and for that reason alone, young lady, I shall overlook it.

Amy: Thank you, Mr. Davis!

Teacher: You may go.

Amy: Thank you, Mr. Davis. Thank you very much indeed! Thank you, sir.

Girls: Here she is.

What did he do?

What did he say?

Come on, tell us, what happened?

Amy: I just said that if ever told my mother the way he treated me, she'd take me out of his old school. She's never been "reconciliated" anyway, since my father lost his money and she's had to suffer the "degradation" of me being thrown in a lot of ill-mannered girls, who stick their nose in refined people's business.

In this classic movie, we enjoy the four little girls' experiences and fates respectively. At first Amy, the youngest daughter, studies in a school of old fashion and inflexible rules. She is not well disciplined, which we can figure out from her scribbling at class and her classmates' comments about her. She is almost fed up with all of these. In this scene, Amy was being criticized by her strict teacher after class.

In class Amy was not concentrated, she drew a pejorative picture of the high-nosed poor-sighted teacher, which made the rigid teacher very angry and annoyed. "I can see nothing for me to do but to stop by and show your mother how instead of doing your sums, you cover your slate with sketches. And most uncomplimentary sketches." "Sketches” here is translated as “鬼画符”, which is a success of domestication for Chinese audiences, since it conforms to Chinese convention so well that it seems natural! The response of the angry, rigid teacher has been explicitly imaged out in front of us, vivid and impressive. Although Amy luckily won the teacher's forgiveness with her sincere begging and request, she could not resist the other schoolgirl's gossips and satires. When getting out of the classroom, she was surrounded by all the other annoying girls who had been waiting outside for quite a long time, asking questions about this and that, which made her so frustrated. Amy was not timid and frail; she didn't tell what had really happened on her by the teacher. She pretended to be so strong to be afraid of nothing; she even told the other girls what would happen if her mother knew her treatment in such a rubbish school. Everything would be just the opposite of their expectation! Her mother would not be "reconciliated", since her father "lost his money" and she had to deal with ill-mannered classmates who were gossiping about others all day long. As we all know from the story, her father has gone to battlefield for the Civil War, it can be analyzed out that "lost his money" here means her father had to be away off his job at home and could not earn any more money. Thus the literal Chinese translation “自从他掉了钱以后......”is obviously not appropriate at all, which will make Chinese audiences a little confused. In terms of skopos rule, intertextual coherence is a key point that should lie between source and target text, while the form it takes depends on both translators' interpretation of the source text and on the translation skopos. Intratextual coherence requires the receivers can understand without difficulty. According to Skopos Theory, taking the constraints of film dialogue translation, timing and spacing, into consideration, we can conclude that it can be adjusted to “自从他参战没了收入以后，......” and this seems much more natural with Amy's facial expression.

\section{B. Example Two}

Here is the conversation between Jo and Amy after getting the money from Aunty March.

Jo: What would you do if you were shut up all day with an old crosspatch who flies off the handle every move you make?

Amy: Jo, don't use slang. Beside, don't forget she gave us the dollar. I'm sure neither of you suffer as I do. You don't have to go to that nasty old Davis' school with impertinent girls who laugh at you and "label" your father 'cause he isn't rich.

Jo: "Libel", "libel". Don't say "label" as if Papa were a pickle bottle.

Amy: I know what I mean and you needn't be "satirical" about it. It's proper to use good words to improve your "vocabulary".

Jo (whistling): Aren't we elegant?

Amy: You'd never be thought so with your slang.

Jo: I hope not. I don't want to be elegant.

Amy: You needn't whistle like a boy.

Jo: That's why I do it. (whistle again)

Amy: I detest rude, unladylike girls.

Jo: And I hate affected, niminy-piminy chicks.

Beth: Birds in their little nest agree.

(Jo and Amy look at each other and smile.)

Here Jo complained about whom she was with everyday. She used two attributes to describe the troublesome old woman, "What would you do if you were shut up all day with an old crosspatch who flies off the handle every move you make?" One is an adjective phrase and the other is an attributive clause. According to Chinese way of understanding 
and thinking, as well as the film translation features, the dialogue translator put them into two attributive adjectives standing along side by side, which are more convenient for Chinese audience to grasp the information conveyed by the informational source conversation. We can conclude that “一个爱挑剔脾气坏的老女人”is a good version for the principle of naturalness and legibility in film translation. And this part fits well in the whole sentence “如果你得整天和 一个爱挑剔、脾气坏的老女人闷在一起, 你会是什么感受? ”

Amy considered herself even unluckier, "You don't have to go to the nasty old Davis' school with impertinent girls who laugh at you and 'label' your father 'cause he isn't rich." "'Libel', 'libel'. Don't say 'label' as if Papa were a pickle bottle." said Jo. This interesting conversation lies in the confusion of Amy about the words "label" and "libel". She intended to take the use of "libel" meaning "slander" or "defame", bur she took "label" instead, which means "put label on something, such as a pickle bottle". Jo, as a quick-witted and sharp-toughed addressee, who was also annoyed by the reputation-damaging words by Amy's ill-mannered classmates, could not hold on her patience any more. She corrected Amy; shouting, "libel', 'libel"” clarifying that she should make clear of these two words. These two sentences are of authentic audio effects with evident English language linguistic features. This is the Chinese translation: “你们又不用 去那又烂又老的达维斯学校, 跟那些没教养、还嘲笑你的衣着, 并“诽谤”你的父亲是穷人的女同学一起上课.” “是 “定义'才对吧, 别把爸爸念成泡菜罐头的名字.” It has to be admitted that the problem exists in the English-Chinese linguistic difference and it would be absolutely infeasible if we put the words literally. So the translation here is unsuccessful and unsatisfactory. According to Skopos Theory and dynamic concept, text is made meaningful by its receivers and for its receivers. Here, it is a typical demonstration of film as a multimedia source, a more complicated information source. Vermeer sums text as "an offer of information" from which the receiver selects the items they find interesting and important, or "adequate to the desired purposes". If the dialogue is translated like the original subtitle, the skopos of the film producer has not been smoothly transferred, much less to say the intertextual coherence and the intratextual coherence. Chinese audience would be puzzled with the abrupt mention of “泡菜罐头”. Under this kind of situation, we need to employ some translation skills. We can delete some of the original information for the sake of the skopos rule. In all, the literal translation is not acceptable here. In this circumstance, the skill of a good translator is of great importance.

As we all know, shortness and informality is one of the major characteristics of film dialogue. When reproached by Amy for rudeness and inelegance, Jo showed no sign of confession and acknowledgement, she denied, "I hate affected, niminy-piminy chicks" which created out a vivid image of Jo with her individualized personality. Taking all these into consideration, “chicks" here is put into “毛头姑娘”, which is lexically accurate and contextually appropriate and natural. The images in our mind are so vivid and impressive, and of more appeal.

\section{Example Three}

Finally, Meg married Brooke despite of Jo's reluctance. After Meg's wedding, Jo alone sat under a big tree, weeping. Laurie, who has been loving her since knowing her, came to give her consolation and he expressed his admiration.

Jo: I can't, Laurie. I'm sorry. So desperately sorry. I'm so grateful to you, and so proud and fond of you. I don't know why I can't love you the way you want me to. I've tried, but I can't change the feeling, and it would be a lie to say I do if I don't.

Laurie: Really truly, Jo?

Jo: Really truly, dear. I don't think I'll ever marry.

Laurie: Yes, you will. You'll meet some good-for-nothing, no-account idiot and you'll fall in love with him, and work, live and die for him. I know you will. It's your way. And I'll have to stand by and see it. Well, I'll be hanged if I do.

Jo: Laurie, where are you going?

Laurie: To the devil, and I hope you'll be sorry.

Jo: Laurie, please...

The Issue of Jo and Laurie is a hot topic in this classical literature. Laurie loved Jo ever since he had known her. He had tried to show it, but Jo had always kept away from him. Under a big tress, Jo felt depressed of Meg's marriage out of the family circle, Laurie came to console her. Instead of beating about the bush, Laurie came straight to the point. But Jo didn't get caught up in Laurie's passion. She loved him, yes, but as a dear dear brother---- not as a husband or lover. Frankly speaking, I felt sorry that Jo denied Laurie; I still wish Jo could of married to Laurie, since Laurie was really a gentleman and he loved Jo with all his heart. After getting Jo's refusal, Laurie was terrible hurt, and did not believe that Jo would never marry. "Yes, you will. You'll meet some good-for-nothing, no-account idiot and you'll fall in love with him, and work, live and die for him. I know you will. It's your way. And I'll have to stand by and see it. Well, I'll be hanged if I do.” This is the Chinese translation: “不，你会的。有天你会碰上一个一无是处、不能依赖的笨蛋，你会 爱上他, 为他工作一辈子, 然后就这样死去。我知道你会的, 这就是你要的方式。我会站在你身旁看好戏的。 我一定会这样做, 就算会被吊死!” It is somewhat mistaken, since the gentleman was not in such a terrible mood. He meant seeing Jo loving another man he would have nothing to do, he would have no way out, but to see Jo marry him, and he was sure it would be as pains-taking as being hanged. The original translation in the film will provoke an illusion that Laurie's affection would explode into resentment, he would went to another extreme. So the suggested translation 
version is “......我会站在你的身旁, 看着这一切, 哦, 我将像受绞刑一样悲惨的! ”

As for Jo, she was strong enough to resist what must have been terrible pressure, especially considering that Laurie was wealthy. She was very sensible and she is a wonderful role mode for women who are independent and know what they want and what's truly best for them.

\section{Example Four}

Many years later, Laurie married Amy, who was suited for him. In this scene, Jo met Laurie with surprise and happiness.

Jo: Laurie. Oh, my Laurie!

Laurie: Jo dear. Are you glad to see me?

Jo: Glad? My blessed boy! Words can't express my gladness. And where is your wife?

Laurie: They all stopped in at Meg's, but I couldn't wait to see you. They'll be along presently.

Jo: Let me look at you.

Laurie: Don't I look like a married man and the head of a family?

Jo: Not a bit, and you never will, although you have grown bigger and bonnier. But you're the same scapegrace as ever, despite that very elegant mustache. You can't fool me.

Laurie: You have to treat me with more respect.

Laurie: Jo, dear. I want to say one thing, then we'll put it by forever.

Jo: No, Laurie, please. I think it was always meant to be, you and Amy. It would have come about naturally if only you'd waited.

Laurie: As you tried to make me understand.

Jo: But you never could be patient.

Laurie: So then we can go back to the happy old times? The way you wanted it, when we first knew one another.

Jo: We never can be a boy and a girl again, Laurie. Those happy old times can't come back.

We shouldn't expect them to. We are man and woman now; we can't be playmates any longer. But we can be brother and sister, to love and help one another, all rest of our lives, can't we, Laurie?

Although they were not young and they were not lovers any more, they were still brother and sister, and there still maintained good friendship between them. In Jo's eyes, Laurie was still the same as before. "Not a bit, and you never will, although you have grown bigger and bonnier. But you're the same scapegrace as ever, despite that very elegant mustache. You can't fool me.” Those happy old times would remain forever in their sweet memory. In the original film, it is translated as: “一点不像, 你永远也不会像。但你却长大了, 变得开朗了, 没错, 你仍旧和以前一样优雅, 尽 管你留了好看的八字胡, 你骗不了我的。” Obviously, “scapegrace” has been mistakenly translated as “开朗”, in fact, the Chinese equivalence for it is “饭桶; 不可救药的恶棍; 流讯”. “Scapegrace” has been used by Jo to make a joke and to show casualness and familiarity with her old intimate friend, whom she had not met for so long. In terms of skopos rule, in order to accomplish the purpose of this whole sentence and the specific function of this word, we can cut “scapegrace” as “臭小子” in Chinese. The sentence by Jo comes into: “一点不像, 但你却长壮了、结实了。不过你 还和以前一样, 一臭小子, 尽管你留了好看的八字胡, 你才骗不了我! ” Thus the intratextual and intertextual coherence here can be achieved, which can accord with the following Laurie's response, "You have to treat me with more respect." Otherwise, Chinese audience would be in the dark of "with more respect". Didn't Jo respect him? The source information has been transferred with fidelity. Everything conforms to logical thinking. Their dialogue helps to image the characters so vivid and live that audience can enjoy the warmth and beauty of domestic life and the great bountiful felicity in the March family. Jo and Laurie's sentiment was so pure and so respectful that they could be brother and sister, to love and help one another. In this scene, we can also find that Jo has stood as an example for the power of women in the nineteenth century and by not marrying anyone, i.e. neither the gentleman nor Laurie, she could show to the world that women can live happily without the support of any man. I adore this book with all my heart, quite sure that I shall cherish it for as long as I shall live.

\section{E. Example Five}

Beth was seriously ill with scarlet fever, lying on the bed, more or less invalid. After doctor's visiting, Jo was weeping alone.

Laurie: Is that bad?

Jo: She doesn't know me. She doesn't look like my Beth. How are we going to bear it? Mother and Father, they seem so far away.

Laurie: I'm here. Hold on to me, Jo, dear. Poor Jo, you are all worn out. What does the doctor say?

Jo: We are sending to Marmee. If she were only here.

Laurie: She will be. Grandfather and I got fidgety and thought your mother ought to know. She' $d$ just never forgive us if Beth... Well, if anything happened... So I telegraphed yesterday. She'll be here, on the 2:00 train tonight, and I'm going to meet her.

Jo: Oh, Laurie! Oh, Marmee!

(Jo is so excited to kiss Laurie.) 
Jo: I beg your pardon, but you're such a dear. I couldn't help flying at you.

Laurie: Fly at me again. I'd rather like it.

Jo: Laurie, you are so silly.

Laurie: I'd better go.

Laurie asked Jo, "What does the doctor say?" "We are sending to Marmee. If she were only here." said Jo. Here "we are sending to Marmee" is a present continuous tense, combining it Laurie's question, we can conclude that it was used not to describe the present situation, but to express what they should do. “我们得给妈妈发个电报, 她能在这儿就好 了!"could be more suitable and natural in the context.

As has been discussed ahead, film, is a kind of multimedia, both a visual medium and an aural one. Audience of film watch what characters are doing and hear what they are talking about, messages reach the audience through visual and acoustic channels. Obviously the fascination of film lies in harmonious cooperation between visual and acoustic channels, which demands the target language should cope with the original images in the film as naturally as possible. From cognitive study, messages in films are supposed to act directly on the sense of sight of the audience, not on the sense of hearing. The translation of utterance should be synchronized with the settings of the scenes, the identity of the characters, their movements, gestures, facial expressions, pauses and lip movements. So the original translation of "I beg your pardon, but you're such a dear. I couldn’t help flying at you.”, “哦，我对不起你，你是这么好的人，我却无 法跟你一同飞翔." can not meet the basic requirement. From Jo's movements, we can figure it out that "fly at you” here is a rhetorical saying, which means "hug you" or "hold on to you", since Laurie was such a big comfort for Jo in depression. Personally speaking, we can make it as “哦，真不好意思，你真是太好了，我忍不住要抱着你!”, then the principle of synchronization in terms of extralinguistic and paralinguistic factors in the art of film can be assured.

\section{CONCLUSION}

As movies are playing an increasingly indispensable role in the intercultural communication, film translation has become more and more important. In film translation academic studies, the issue is always discussed from the traditional perspective of faithfulness, expressiveness and elegance, which limits the study of film title translation and ignores the special requirements. In practice, there are many problems. However, the development of Skopos theory provides a new perspective for film title translation.

Based on Skopos Theory, which puts particular emphasis on the transfer of "skopos" or "purpose" into target text, different strategies should be adopted in different circumstances. As for their detailed analysis on roles in translation, it has to be pointed that the most crucial one is the receptor of the target text, the target film audience in film translation. Thus the film translation should be target-audience-oriented. The audience's expectation for the original film must also be probed into. The three principles of Skopos Theory - the Skopos Rule, the Coherence Rule and the Fidelity Rule - are very illuminating for film dialogue translation.

This applicability of Skopos Theory and the special principles have been verified and supported by the case study of the film Little Women (1933). Some ways of translation have also been suggested after examining some ill-considered translated dialogues.

In a word, just like a glimpse of sunshine, Skopos theory offers valuable enlightenment to translation study. With comprehensive cultural background knowledge to completely understand the source book and with target-audience-oriented Skopos in mind will help us open our vision, improve the ability to read and gain a satisfying target language version. Then the film dialogue translators can successfully transfer the information as well as the artistic appeal of the foreign films for the target-culture-audience.

\section{REFERENCES}

[1] Basil, Hatim \& Ian Mason. (1997). The translation as communicator. London: Rouledge.

[2] Bell, A. (1984). Language style as audience design. Language in Society 13, 145-204.

[3] Catford, John C. (1965). A linguistic theory of translation. London: Oxford University Press.

[4] Christiane Nord. (2001). Translation as a purposeful action. Shanghai: Shanghai Foreign Language Education Press.

[5] Danan, Martine. (1991). Dubbing as an expression of nationalism. Meta 36.2, 16- 36.

[6] Hans J. Vermeer. (2000). Skopos and commission in translational action. London: Rougledge.

[7] Martin, M. (1977). The languages of films. Beijing: China Film Press.

[8] Nida, Eugene A. (2001). Language, culture and translating. Shanghai: Shanghai Foreign Language Education Press.

[9] Zhongfang Mei. (2010). On the translation strategies of English film title from the perspective of skopos theory. Journal of Language Teaching and Research 1.1, 66-68.

Yan Chang was born in Jingzhou, China in 1981. She received her M.A. degree in foreign linguistics and applied linguistics from Ocean University of China in 2006.

She is currently a lecturer in the School of Foreign Languages, Qingdao University of Science and Technology, Qingdao, China. Her research interests include linguistics, English rhetoric and translation. 